\title{
Losses Pipes in Sprinkler Irrigation Based IoT
}

\author{
Eko Noerhayati ${ }^{1}$, Soraya Norma Mustika ${ }^{2}$, Margianto $^{3}$, Bambang Dwisulo ${ }^{4}$, \\ Anita Rachmawati ${ }^{1}$
}

\author{
${ }^{1}$ Department of Civil Engineering, Faculty of Engineering, Universitas Islam Malang, Indonesia \\ ${ }^{2}$ Department of Electrical Engineering, Faculty of Engineering, Universitas Negeri Malang, Indonesia \\ ${ }^{3}$ Department of Mechanical Engineering, Faculty of Engineering, Universitas Islam Malang, Indonesia \\ ${ }^{4}$ Department of Electrical Engineering, Faculty of Engineering, Universitas Islam Malang, Indonesia \\ *Corresponding author. Email: eko.noerhayati@unisma.ac.id
}

\begin{abstract}
Sprinkler irrigation is an alternative irrigation technology that is theoretically more efficient than open channel irrigation. Sprinkler irrigation can reduce water losses caused by percolation and runoff. In industrial age 4.0, modern technology is highly influential in everyday life, including the IoT in sprinkler irrigation. Research and design of sprinkler irrigation based on IoT has been carried out extensively. Still, the understanding of water loss factors is not fully understood, and something new is needed to determine a better assessment of incidence. For this, the power loss test in sprinkler irrigation canals based on IoT is carried out on a laboratory scale. The statistical analysis shows that the relationship between discharge and head loss is $y=-3 E-08 x 4+4 E-07 x 3-2 E-06 x 2+2 E-06 x+$ 0.0002 with a value of $R^{2}=0.9495$.
\end{abstract}

Keywords: Sprinkler, IoT, Headloss, Energy, Laboratory

\section{INTRODUCTION}

Indonesia is an agricultural country; therefore, farmers have an essential role in meeting food needs in Indonesia, and irrigation systems are vital for farmers to meet their crop needs. Conventional irrigation with open channels is irrigation that wastes water because a lot of water is wasted due to leaks and evaporation [1].

Sprinkler irrigation can overcome these problems with greater efficiency in your water supply. The bulk irrigation system in its application can save water. The time it takes to water the plants and the pipe's height affects all the parameters observed, namely the coefficient of uniformity of water distribution (CU), the water spray rate, and water spray distance [2]. The combination of the use of piped irrigation with an SRI water supply system shows high productivity and efficiency in water use [3]. In the industrial era 4.0, modern technology is very influential in everyday life, including IoT in sprinkler irrigation. IoT allows users to control irrigation pumps and sprinklers remotely [4]. Research on [5] sprinkler irrigation shows that the distribution of automatic sprinklers combined with manual experiments with the $\mathrm{T}$ value results in the calculation $<T$ from the table. Acceptance of the Ho value indicates that the design of the sprinkler machine can work well. Meanwhile [6], in this research on bulk irrigation network design, the water requirement for orchids is determined by the direct method, the water content method. The principle of operation of this method, the plant's water requirement is the difference between the water supplied to the plant and that used by the plant.

\section{BACKGROUND}

One solution to solve the problem of reduced water supply needed by farmers in Indonesia is to provide water with a sprinkler irrigation system [7]. This technology will help people irrigate crops more efficiently according to prevailing weather conditions.

\subsection{Sprinkler Irrigation}

Sprinkler irrigation is an alternative irrigation technology that is theoretically more efficient than open channel irrigation [9]. Sprinkler irrigation can reduce water loss caused by percolation and runoff (U Haryati - 2014). Sprinkler irrigation is also known as bulk irrigation. This bulk irrigation system uses compression energy to shape and distribute water to the land. The pressure is an essential factor that determines sprinkler performance. According to previous research, the 


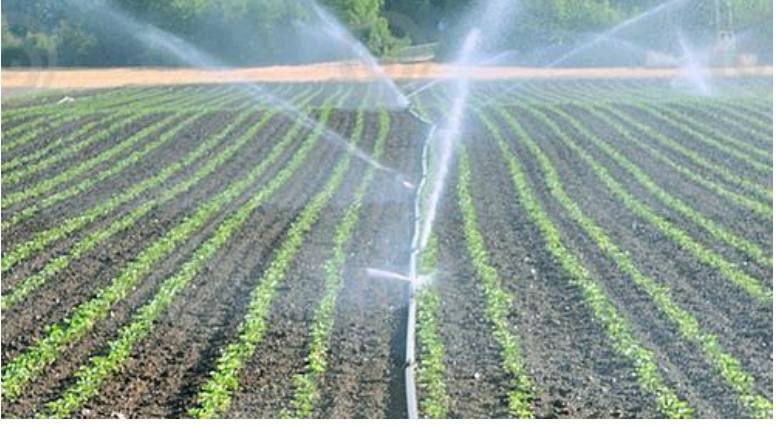

Figure 1 Sprinkler Irrigation

irrigation sprinkler method uses forces between 70 and $700 \mathrm{kPa}$ to create rain-like grains. This system can be used in a variety of terrain conditions, both flat and rough [10].

Excessive irrigation water supply will waste a great deal of water, resulting in inefficiency in field 10 . Advantages of sprinkler irrigation are:

- More accessible water metering,

- Does not interfere with agricultural work, and saves land,

- High water efficiency,

- Investment considering needs, and distribution networks are flexible and allow automation to make o\&m more economical.

Figure 1 shows an example of an irrigation sprinkler in a rice field. Mismanagement of water used for irrigation not only results in water shortages but also affects agricultural production [11]. Research on sprinkler irrigation has been widely carried out [12]. It stated that sprinkler irrigation could use the Arduino to receive information and transmit the ESP8266 Wi-Fi module wirelessly to websites via the internet. In automatic irrigation In an automation system, water availability for plants is monitored through sensors, and as needed, watering is done through controlled irrigation [13]. Farmers can obtain the accurate status of field conditions and can thus make necessary changes if needed [14].

\subsubsection{Sprinkler Discharge}

Determination of sprinkler discharge is based on the volume of water that comes out of the sprinkler in units of litres per minute. The discharge is determined by Equation 1.

$$
Q=V / t
$$

where:

$$
\begin{array}{ll}
\mathrm{Q} & =\text { Sprinkler Discharge }(1 / \mathrm{dt}) \\
V & =\text { volume }(\mathrm{l}) \\
T & =\text { time }(\mathrm{dt})
\end{array}
$$

\subsubsection{Headloss}

The loss of compression height in the pipe in the sprinkler irrigation channel is divided into two factors [15]. The first is due to the friction between the liquid and the pipe wall or the object; the second is due to other factors caused by gaskets, curves, etc. The calculation of the first factor is called mayor losses with Equation 2.

$$
h f=f \frac{L}{D} \times \frac{v^{2}}{2 \times g}
$$

where:

$$
\begin{array}{ll}
h f & =\text { Losses mayor }(\mathrm{m}) \\
f & =\text { friction factor } \\
L & =\text { long pipe }(\mathrm{m}) \\
V & =\text { flow velocity }(\mathrm{m} / \mathrm{dt}) \\
g & =\text { gravity }\left(9,81 \mathrm{~m} / \mathrm{det}^{2}\right)
\end{array}
$$

for the calculation of the second factor is called Minor Losses with Equation 3.

$$
h k=k f \frac{v^{2}}{2 \times g}
$$

where:

$$
\begin{array}{ll}
h k & =\text { Losses minor energy } \\
k f & =\text { coefficient of friction loss } \\
V & =\text { flow velocity } \\
g & =\text { gravity }\left(9,81 \mathrm{~m} / \mathrm{det}^{2}\right)
\end{array}
$$

The value of $k f$ or the friction coefficient is determined by looking at the type of pipe connection based on Table 1, while the turn loss coefficient uses the referenced Table 2. For turns Loss Coefficient, the $k f$ value is used in Table 2 .

\subsection{Water Flow Sensor}

The implementation of the water flow sensor component aims to determine the performance of the sprinkler irrigation system's suitability based on IoT.

Table 1. Coefficient of Friction Loss

\begin{tabular}{lll}
\hline No & Pipe Connection & $\boldsymbol{k f}$ \\
\hline 1 & Ball Valve & 10,0 \\
\hline 2 & Angle Valve & 5,0 \\
\hline 3 & Gate valve, wide open & 0,2 \\
\hline 4 & Gate valve, halp open & 5,6 \\
\hline 5 & Return bend & 2,2 \\
\hline 6 & Tee & 1,8 \\
\hline 7 & Elbow $90^{\circ}$ & 0,9 \\
\hline 8 & Elbow $45^{\circ}$ & 0,4 \\
\hline Source: Soelarso $(2000 ; 34)$ &
\end{tabular}


Table 2. Turn Loss Coefficient

\begin{tabular}{llllllllll}
\hline $\boldsymbol{\theta}^{\circ}$ & & 5 & 10 & 15 & 22,5 & 30 & 45 & 60 & 90 \\
\hline \multirow{2}{*}{$\boldsymbol{f}$} & smooth & 0,016 & 0,034 & 0,042 & 0,066 & 0,130 & 0,236 & 0,471 & 1,129 \\
\cline { 2 - 12 } & coarse & 0,024 & 0,044 & 0,062 & 0,154 & 0,165 & 0,320 & 0,684 & 1,265 \\
\hline
\end{tabular}

Source: Soelarso $(2000 ; 34)$

From the results of the undertaking, the monitoring function of the water discharge sensor for the sprinkler irrigation network will be obtained.

The water flow sensor works to detect the flow of water in the pipe during irrigation. The way to read it is when the servo motor receives a command to open the water flow in the line, the water discharge sensor will automatically read the volume data and the water flow data. After passing the water flow sensor, the water flow in the pipe is divided into 2 . Then the water will come out through 2 sprinklers to water the plants. Figure 2 shows a water flow sensor device installed in an irrigation network pipe.

A sound irrigation system can produce good agricultural quality [16]. Remote control monitoring of sprinkler irrigation systems based on IoT (Internet of Things) is a sprinkler irrigation network design that can be used remotely with a smartphone. The design and layout of the IoT-based sprinkler network system's microcontroller components can be integrated with a smartphone in the Blynk application and, of course, connected to the Internet network.

In previous research, [17] which has the title Horticultural plant growth monitoring and control system in SmartkGarden, explains that the application is to monitor the growth of horticultural plants in a smart garden where the system can control temperature, monitor water levels in the soil, and You can provide system reports through a user-friendly interface application, namely a smartphone [16]. States of IoT (Internet of Things) technology, to minimize manual intervention and produce smart hydroponic systems

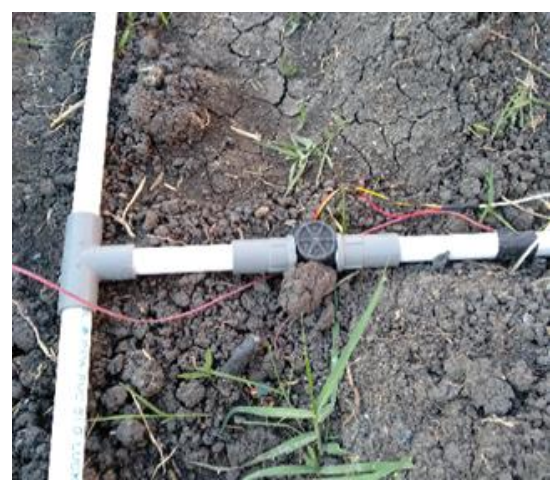

Figure 2 Water Flow Sensor implementation with technology's help. The planning and design of a sprinkler irrigation system must consider the factors that affect the water flowing into the sprinkler, including the diameter and the pipe network system to the transmitter. Flow in pipes with multiple outlets is considered an advanced problem in hydraulic engineering [18]. Flow in pipes is known that flow velocity is found to be the dominant parameter compared to solids concentration [19].

The objective to be achieved in this research is to determine the loss of water that occurs in the sprinkler pipe network system from the water reservoir to the nozzle by using IoT to determine the relationship between the discharge flowing in the pipeline and the total loss of energy generated in the design of a laboratory-scale sprinkler irrigation system.

\section{RESEARCH METHODS}

This study looked at the discharge of water from the reservoir and the discharge of water into the sprinkler pipeline using an automatic microcontroller connected to a smartphone. The research was carried out in rice fields planted with the plants. The Blynk application displays The ultrasonic sensor is installed in the tankthe Data obtained by observing the water flow that automatically passes through the pipe using a remote control. Treatments were repeated eight times.

The tools used in this study are the following:

1. DN 15 sprinkler as a water spraying device

2. two water tanks of 550L size

3. two iron posts $3 \mathrm{~m}$ high

4. Pumps to take from the well to the tank

5. 1 " aw pipe, $3 / 4$ aw pipe, distribution of the water from the reservoir, and the sprinkler

6. Vertical pipe with a diameter of $1 / 2$ to the sprinkler

7. The meter as a measuring tool

8. NodeMCU V3 Lolin module (microcontroller)

9. Automatic taps with modified servomotor

10. Ultrasonic sensor to measure the water level at which the signal will be sent to the smartphone that has been connected to Blynk. An app on the smartphone via Blynk

11. Microcontroller kit with NodeMCU

12. Water flow meter (digital discharge metering device) connected to a microcontroller 


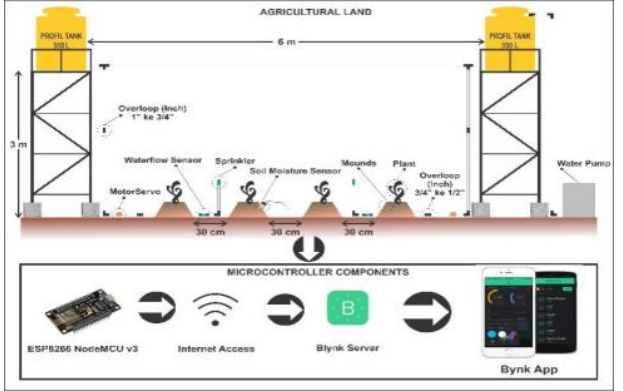

Figure 3 Schematic of microcontroller irrigation performance and circuit

To calculate head loss or energy loss using the discharge data in a series of sprinkler irrigation equipment. Figure 3 shows the performance schematic and a series of microcontroller irrigation tools, while Figure 4 shows the smartphone screen using Blynk. Figure 5 describes the general stages of the investigation. To measure the flow of water released from the reservoir to the sprinkler using the water flow.

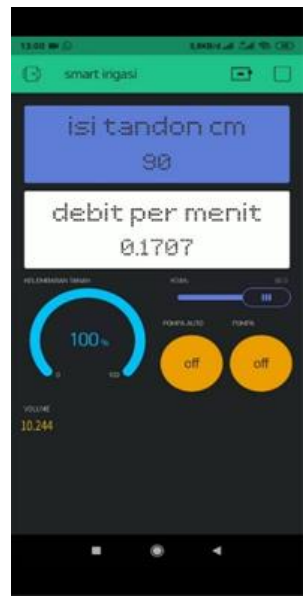

Figure 4 Smartphone display using Blynk

Automatic faucets are used to automatically open or close the faucet using the Blynk app on a smartphone. The control panel is used to mounting sensors and electronic equipment together and as a module for connecting to the Blynk app on a smartphone.

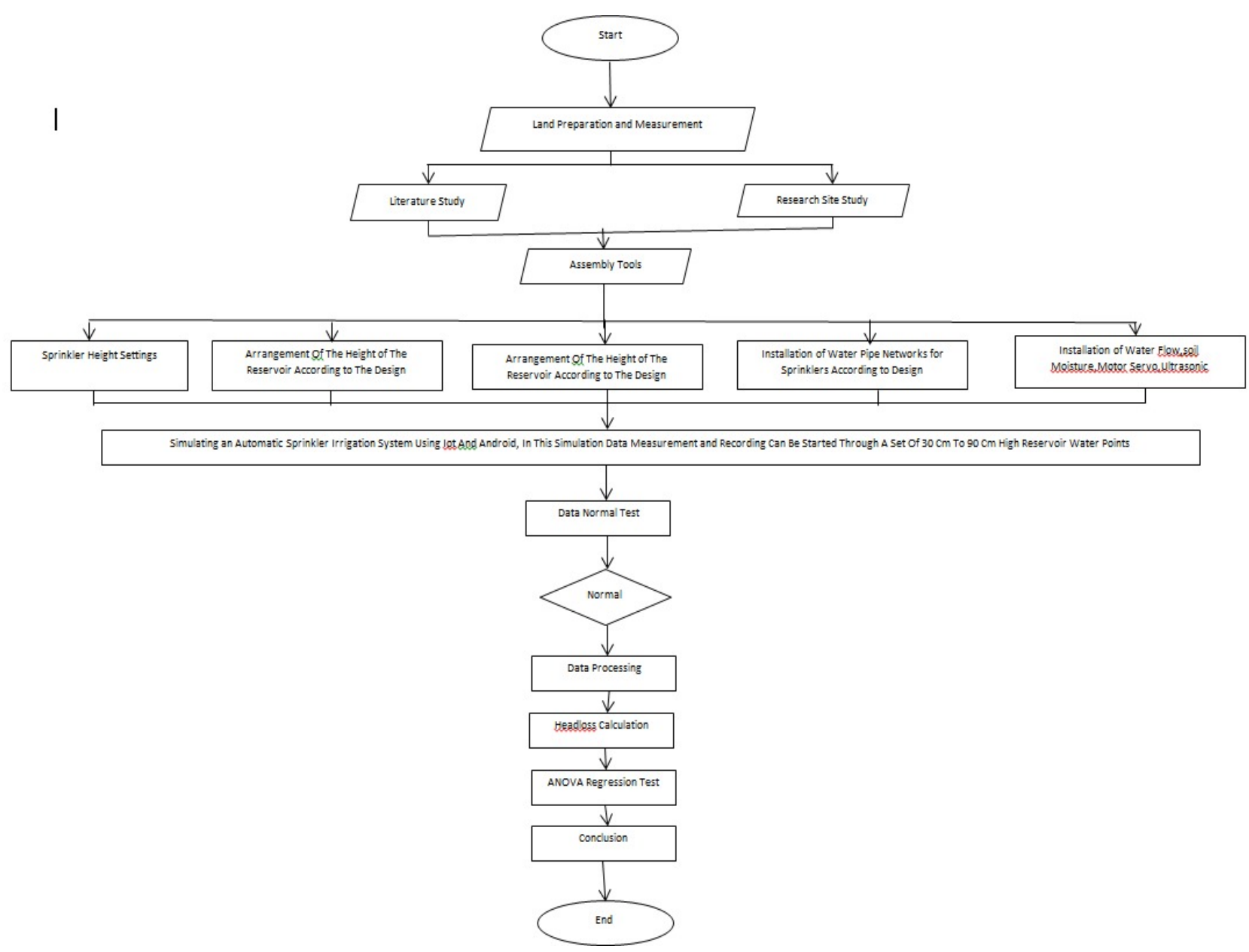

Figure 5 Research flowchart 


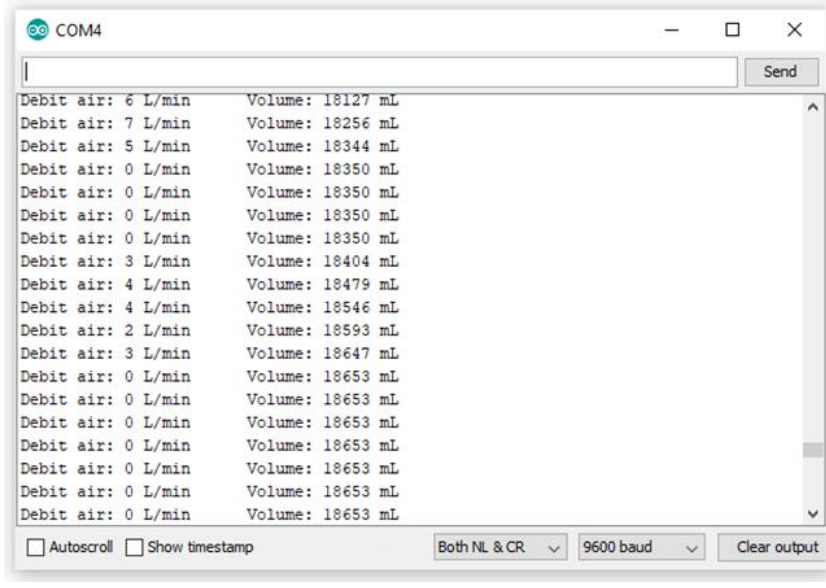

Figure 6 Calibration Results on Serial Monitor

\section{RESULT AND DISCUSSION}

The water flow sensor is a sensor to monitor the intensity of the water entering through the sensor,[20] where the test is done by blowing to move the turbine on the sensor. The results will be read on the serial monitor and displayed in the Blynk app on a smartphone. The following are the results of the water flow sensor calibration to test the turbine operation:

The calibration screen on the serial monitor is running, which means that the program has successfully connected to the microcontroller and can read the response given to the water flow sensor. The following is a water flow sensor monitoring screen on a smartphone.

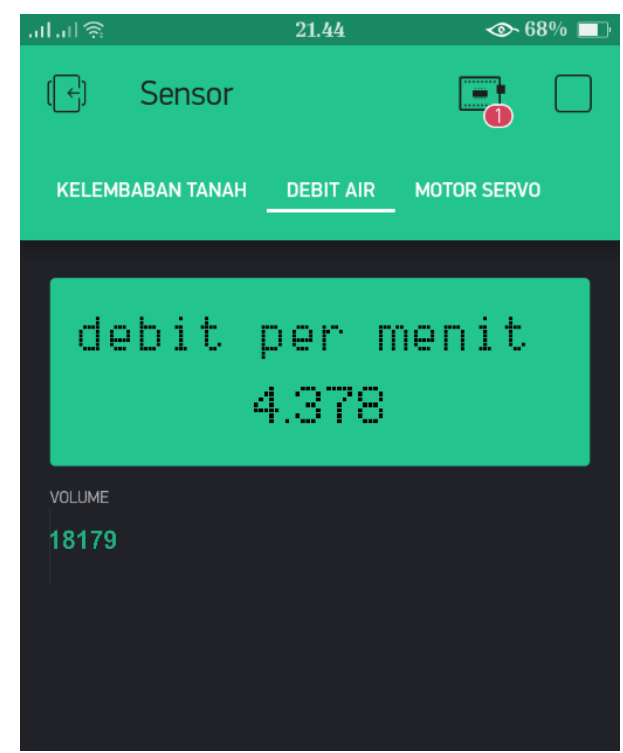

Figure 7 Display of Water Flow Sensor Monitoring
Table 3. Water Flow Sensor Performance Test Data

\begin{tabular}{|c|c|}
\hline No & Discharge \\
\hline 1 & 0.0001623 \\
\hline 2 & 0.0001604 \\
\hline 3 & 0.0001596 \\
\hline 4 & 0.0001591 \\
\hline 5 & 0.0001580 \\
\hline 6 & 0.0001596 \\
\hline 7 & 0.0001593 \\
\hline 8 & 0.0001560 \\
\hline
\end{tabular}

The $16 \times 2$ LCD function is used to monitor the intensity of the water entering the sensor. Furthermore, the value display function is useful to know the intensity volume value of the water coming out of the sensor. The observations made are to test the operation of the sensor. The following table showed the test results for the discharge sensor performance for 1 minute and was carried out eight times.

Table 3 is the result of 8 times experiment with reference in Figure 3 as irrigation and monitoring of IoT-based sprinkler irrigation systems via smartphones. From these data, it can be concluded that the water flow sensor can read the flow of water during watering the plants.

\section{Head Losses}

Head loss is a loss of pressure or energy in the flow. The pressure drop is calculated to know the energy loss in a series of experiments. Table 4 shows the results of the head loss calculation for experiments 1-8. Based on the experimental results' discharge value, the value of energy loss is calculated according to the design of the pipe in the irrigation sprinkler shown in Figure 8.

\section{Mayor Losses}

It is a loss in compressive height due to friction that occurs in the pipe, to determine the value of major losses, the Hazen-William equation (Equation 2) can be used.

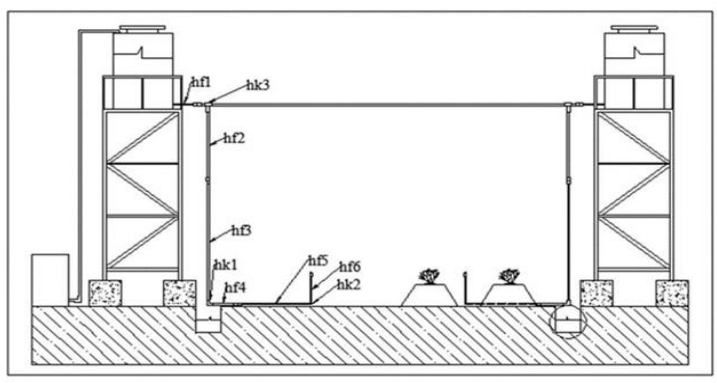

Figure 8 Schematic of Hedloss and Major Losess 
To determine the value of $f$ (friction factor) or the coefficient of friction can use Equation 4.

$f=\frac{0,25}{\left[\log \left(\frac{k}{3,7 \times D}+\frac{5,74}{R e^{0,9}}\right)\right]^{2}}$

where:

$f \quad=$ friction factor

$k \quad=$ high roughness

Re $\quad=$ Reynolds Number

\section{Minor Losses}

It is a loss of compression height due to accessories in the pipe series such as connection, pipe bends, etc. To determine the value of minor losses due to joints using Equation 3.

The value of $k f$ or the coefficient of friction loss can be determined by observing the pipe connection type. The value of the largest and smallest head losses can be calculated using the Darcy-Weisbach equation. Table 4 shows the results of the pressure drop calculation according to the flow in the pipe.

To determine the relationship between discharge and lead loss is to perform an ANOVA statistical test which results are $y=-3 E-08 x 4+4 E-07 x 3-$ $2 E-06 x 2+2 E-06 x+0.0002$ with $R^{2}=0.9495$. Figure 9 shows the relationship between discharge and lead loos that occurs in an IoT-based irrigation system.

\section{CONCLUSION}

Based on the research, it can be concluded that the relationship between the flow of water flowing in the pipe and the power loss in the design of the sprinkler irrigation system depends on the type of pipe and the design model of the irrigation system. by sprinkling. In laboratory-scale experiments conducted in the laboratory of the Faculty of Engineering of the Islamic

Table 4. Water Discharge and Head Loss

\begin{tabular}{|c|c|c|}
\hline No & Discharge $\mathbf{~ m}^{\mathbf{3}} / \mathbf{s e c}$ & Head Loss $(\mathbf{m})$ \\
\hline 1 & 0.0001623 & 0.127366 \\
\hline 2 & 0.0001604 & 0.116685 \\
\hline 3 & 0.0001596 & 0.113437 \\
\hline 4 & 0.0001591 & 0.121762 \\
\hline 5 & 0.0001580 & 0.086170 \\
\hline 6 & 0.0001596 & 0.149070 \\
\hline 7 & 0.0001593 & 0.116180 \\
\hline 8 & 0.0001560 & 0.122210 \\
\hline
\end{tabular}

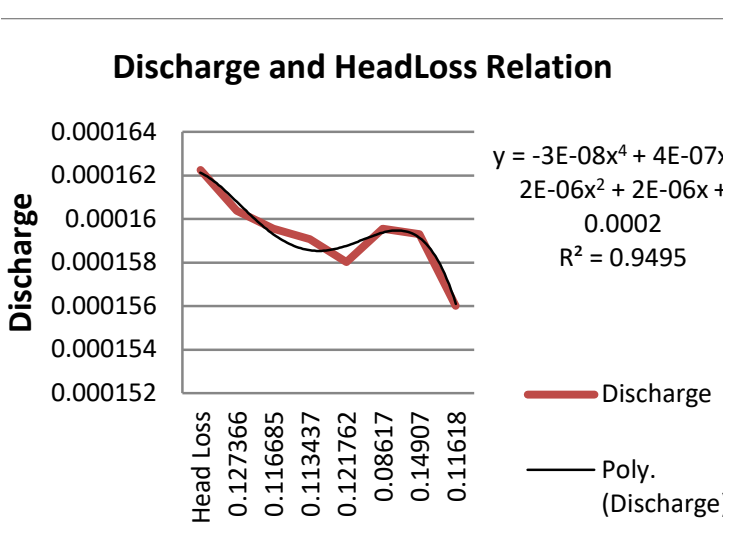

Figure 9 Debit and energy loss correlation

University of Malang, the relationship between $y=$ $-3 E-08 x 4+4 E-07 x 3-2 E-06 \times 2+2 E-$ $06 x+0.0002$ with $R^{2}=0.9495$.

\section{ACKNOWLEDGMENT}

This work was supported by a research grant from the Indonesian Ministry of Research and Technology

\section{REFERENCES}

[1] O. R. Paramita, J. S. Fidari, and E. Purwati, "PERENCANAAN JARINGAN IRIGASI CURAH (SPRINKLER) PADA TANAMAN BAWANG MERAH (ALLIUM CEPA L.) DI DESA KALIAKAH KECAMATAN NEGARA KABUPATEN JEMBRANA PROVINSI BALI.”

[2] A. Putra, I. Ichwana, and S. Chairani, "Efisiensi Keseragaman Distribusi Air Dari Variasi Ketinggian Pipa Pada Sistem Irigasi Curah," J. Ilm. Mhs. Pertan., vol. 2, no. 2, pp. 430-438, 2017.

[3] N. A. Fuadi, M. Y. J. Purwanto, and S. D. Tarigan, "Kajian kebutuhan air dan produktivitas air padi sawah dengan sistem pemberian air secara sri dan konvensional menggunakan irigasi pipa," J. Irig., vol. 11, no. 1, pp. 23-32, 2016.

[4] P. Singh and S. Saikia, "Arduino-based smart irrigation using water flow sensor, soil moisture sensor, temperature sensor and ESP8266 WiFi module," in 2016 IEEE Region 10 Humanitarian Technology Conference (R10-HTC), 2016, pp. 14.

[5] E. Noerhayati, B. Dwisulo, and A. Rahmawati, "Sprinkler irrigation design with microcontroller 
based on IoT," in IOP Conference Series: Earth and Environmental Science, 2020, vol. 456, no. 1, p. 012063.

[6] S. Triyono, A. Tusi, O. Oktafri, and I. Syaifudin, "APLIKASI TEKNOLOGI IRIGASI SPRINKLER DI KELOMPOK TANI SAYUR DESA MARGALESTARI-LAMPUNG SELATAN," 2015.

[7] U. Kurnia, "Prospek pengairan pertanian tanaman semusim lahan kering," J. Litbang Pertan., vol. 23, no. 4, pp. 130-138, 2004.

[8] A. Tusi and B. Lanya, "Rancangan irigasi sprinkler portable tanaman pakchoy," J. Irig., vol. 11, no. 1, pp. 43-54, 2016.

[9] S. Maarif, E. Noerhayati, and A. Rachmawati, "Studi Alternatif Perencanaan Jaringan Irigasi Curah (Sprinkler Irigation) Berbasis Gravitasi Di Desa Poncokusumo," J. Rekayasa Sipil, vol. 7, no. 1, pp. 43-52, 2019.

[10] A. Tusi and B. Lanya, "Rancangan irigasi sprinkler portable tanaman pakchoy," J. Irig., vol. 11, no. 1, pp. 43-54, 2016.

[11] A. Kumar, A. Surendra, H. Mohan, K. M. Valliappan, and N. Kirthika, "Internet of things based smart irrigation using regression algorithm," in 2017 International Conference on Intelligent Computing, Instrumentation and Control Technologies (ICICICT), 2017, pp. 16521657.

[12] P. Srivastava, M. Bajaj, and A. S. Rana, "Overview of ESP8266 Wi-Fi module based smart irrigation system using IOT," in 2018 Fourth International Conference on Advances in Electrical, Electronics, Information, Communication and Bio-Informatics (AEEICB), 2018, pp. 1-5.

[13] S. Vaishali, S. Suraj, G. Vignesh, S. Dhivya, and S. Udhayakumar, "Mobile integrated smart irrigation management and monitoring system using IOT," in 2017 International Conference on Communication and Signal Processing (ICCSP), 2017, pp. 2164-2167.

[14] A. Poojary, "Smart Watering System Using MQTT Protocol in IoT," in Advances in Artificial Intelligence and Data Engineering, Springer, pp. 1415-1424.

[15] A. Priyati, S. H. Abdullah, and K. Hafiz, "ANALISIS HEAD LOSSES AKIBAT BELOKAN PIPA $90^{\circ}$ (SAMBUNGAN VERTIKAL) DENGAN PEMASANGAN TUBE BUNDLE," J. Ilm. Rekayasa Pertan. Dan Biosist., vol. 7, no. 1, pp. 95-104, 2019.

[16] S. Wahyudi, E. Noerhayati, and A. Rachmawati, "Sistem Kinerja Alat Irigasi Curah (Sprinkler) Berbasis Mikrokontroler IoT (Internet Of Things)," J. Rekayasa Sipil, vol. 8, no. 6, pp. 475486, 2020.

[17] D. M. Sari and Z. B. Hasanuddi, "Dewiani,,", Sist. Kontrol Dan Monit. Pertumbuhan Tanam. Hortik. Pada Smart Gard. J. IT, vol. 8, no. 1, 2017.

[18] W. H. Alawee, Y. A. Almolhem, B. Yusuf, T. A. Mohammad, and H. A. Dhahad, "Variation of Coefficient of Friction and Friction Head Losses Along a Pipe with Multiple Outlets," Water, vol. 12 , no. 3 , p. $844,2020$.

[19] J. P. Singh, S. Kumar, S. K. Mohapatra, and G. Nandan, "Experimental Design-Based Analysis on Process Parameters for Head Loss in Pipe Bend," in Advances in Fluid and Thermal Engineering, Springer, 2019, pp. 379-388.

[20] C. Miller, M. Sturdevant, and W. Kaigler, Water flow sensor and monitoring system comprising a water flow sensor. Google Patents, 2013. 